\title{
水圧消散効果に着目した 地中連続排水壁による液状化対策
}

\author{
森河 由紀弘 1 ・田中 雄也 2 ・前田 健一 3 ・張 鋒4 \\ 1正会員 名古屋工業大学助教 都市社会工学科（干466-8555名古屋市昭和区御器所町） \\ E-mail: morikawa.yukihiro@nitech.ac.jp \\ 2学生会員 名古屋工業大学大学院 工学研究科（干466-8555名古屋市昭和区御器所町） \\ E-mail: 27418536@stn.nitech.ac.jp \\ 3正会員 名古屋工業大学教授 都市社会工学科（干466-8555名古屋市昭和区御器所町） \\ E-mail: maeda.kenichi@nitech.ac.jp \\ 4正会員 名古屋工業大学教授 都市社会工学科（干466-8555名古屋市昭和区御器所町） \\ E-mail: cho.ho@nitech.ac.jp
}

\begin{abstract}
近年，我が国には幾度となく大小様々な地震が来襲しており，液状化対策が施されていない構造物や地 盤には深刻な液状化被害が発生している。 そのような中，本研究では過剩間隙水圧の消散やせん断変形の 抑制に着目した「地中連続排水壁」による液状化対策について検討を行った。本研究で検討する地中連続 排水壁は従来の難透水性であるセメント改良土ではなく, 高い摩擦性と排水性を有する地盤材料を用いた 地中連続壁であり，重力場における振動台実験装置や弾塑性有限要素法を用いて対策効果やメカニズムに 対する検討を行った. 検討の結果, 従来の透水性の低い地中連続壁に比べ, 地中連続壁に排水機能を付加 することによって構造物の傾斜量を大きく抑制可能であることが確認された，
\end{abstract}

Key Words : liquefaction, drainage method, water pressure dissipation, shaking table test, FEM

\section{1. はじめに}

1964年の新潟地震や1995年の兵庫県南部地震，2011年 の東北地方太平洋沖地震などにおいて，我が国では幾度 となく大規模な液状化被害が発生しており，様々な被害 が報告されている1)33.ささらに，近年では数分間にわた る長い地震動や複数回の余震などによる液状化被害の拡 大も危惧されている。これまで，液状化による主な被害 としては構造物の沈下や傾斜，噴砂や噴水現象などが考 えられてきたが，噴砂や噴水を伴った地割れへの落下な どによる直接的な原因によるものとして3名，落橋やそ の他間接的要因によるものとして10名，計13名の死亡例 も報告されている4. 一方で，我が国の液状化対策工法 は大きく分けて，セメントなどの固化材を用いて直接地 盤を固化する固結工法，砂杭の圧入等による密度増大工 法，地下水位低下や地盤の不飽和化を行う工法，バーチ カルドレーン等による過剩間隙水圧消散工法(5) ，地中 連続壁によるせん断変形抑制工法8) 100などがある。しか し，重要構造物や大規模な構造物などに対してはこれら の液状化対策が行われていたり，地震にも耐えうる強固
な杭基礎等によって支持されているものの，地中埋設物 や戸建て住宅などの比較的小規模な構造物に対しては十 分な液状化対策方法が検討されているとは言い難い.

このような背景の中，本研究では既設小規模構造物な どに対しても適用性が高いと考えられる過剩間隙水圧消 散工法とせん断変形抑制工法に着目した。 ここで，液状 化対策として用いられる従来の地中連続壁は，原位置擋 拌によるセメント改良土によってその壁体は形成されて おり，高強度ではあるものの透水性は周囲の地盤に比心 て著しく低い，そこで，本研究では地震時における地盤 のせん断変形抑制と過剩間隙水圧の早期消散という両方 の対策効果を得るために地中連続排水壁には従来のセメ ント改良土ではなく, 高い摩擦性と排水性を有する地盤 材料を用いた対策を提案し，その効果を重力場における 振動台実験と2次元，および3次元弾塑性有限要素解析に よる検討を行った．本研究で検討を行った地中連続排水 壁は地盤の液状化や構造物の沈下被害を完全に防止する ための液状化対策ではなく，過剩間隙水圧を早期に消散 させることによって沈下被害を低減させることを目的に した減災型の液状化対策である. 


\section{2. 重力場における振動台実験による検討}

\section{(1) 実験装置と使用材料}

本研究ではメンテナンス性が優れている空圧式加振装 置を備えた重力場での振動台実験装置を使用した．本装 置の主な性能は，最大空圧は1.0MPa，最大振幅は $50 \mathrm{~mm}$, 最大加振質量は $1800 \mathrm{~kg}$ である. 振動台に設置されている せん断土槽の寸法は横幅 $1200 \mathrm{~mm} \times$ 奥行き $1000 \mathrm{~mm} \times$ 高さ 800mmであり，1層30mmの格子枠 $\times 25$ 層から構成されて いる. 本研究で行った振動台実験では，模型地盤に豊浦 砂を使用し，地中連続排水壁には一度水洗いした破砕瓦 を用いた. ここで，破砕瓦とは規格外瓦を粉砕したリサ イクル材料であり，図-1(a)に粒度分布，図-1(b)に透水係 数を示す. 水洗いした破砕瓦の最大粒径は $D_{\max }=9.5 \mathrm{~mm}$, 均等係数は $U_{\mathrm{c}}=6.0$, 曲率係数は $U_{\mathrm{c}}=0.8$ である. また, 水 洗い前の破砕瓦については均等係数が $U$ c=10を超えてお り，比較的粒度分布が良いことがわかる．また，水洗い 後における破砕瓦の透水係数は $k=3.26 \times 10^{-4} \mathrm{~m} / \mathrm{s}$ であり，地 盤材料である豊浦砂の透水係数 $k=1.29 \times 10^{-4} \mathrm{~m} / \mathrm{s}$ に比べ2.5倍 程度高くなっている.

図-2に排水三軸圧縮試験の結果を示す．破砕瓦は中密 な状態（相対密度 : $\left.D_{1}=65.9 \%\right)$ においては内部摩擦角が $\phi=44^{\circ}$ であり，緩い状態 $\left(D_{\mathrm{r}}=25.8 \%\right)$ においても $\phi=41^{\circ}$ を超えている．これは，中密な豊浦砂（ $\left.D_{1}=68.0 \%\right)$ の内 部摩擦角 $\phi=39^{\circ}$ よりも大きい. また，別に行った安息角 試験より，破砕瓦の安息角は $41^{\circ}$ であり，豊浦砂の $31^{\circ}$ に比べて自立性が高いことも確認されている.

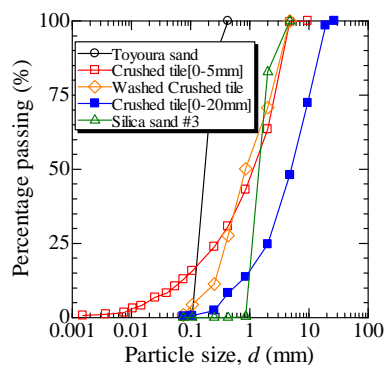

(a) 粒度分布

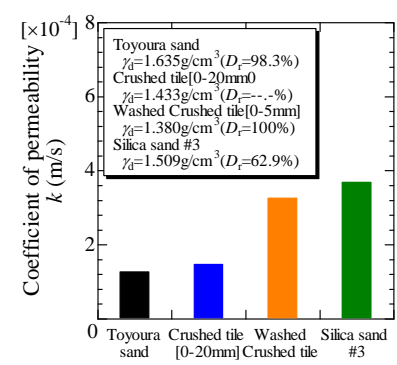

(b) 透水係数
図-1 粒度分布と透水係数

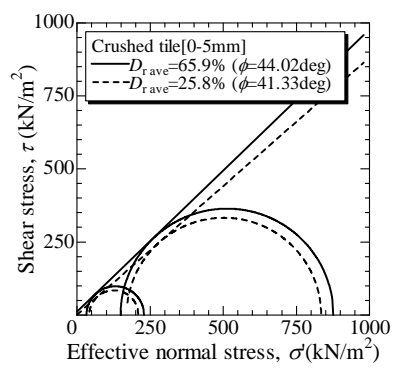

(a) 破砕瓦

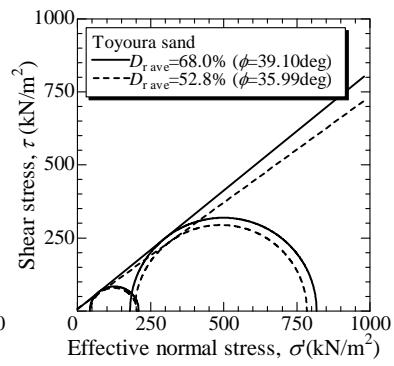

(b) 豊浦砂
図-2 排水三軸圧縮試験の結果

\section{(2) 実験条件}

実験概要図，実験状況を図-3〜4に示す．平面図の上 下方向が加振方向であり，図面左側が未対策のCase A, 図面右側が地中連続排水壁（破砕瓦）による液状化対策 を行ったCase Bである．模型縮尺は1/30を想定しており， 構造物寸法は $200 \mathrm{~mm} \times 200 \mathrm{~mm} \times 25 \mathrm{~mm}$ ，質量は2.7kg，設 置圧は0.66 kN/m² でる. Case Aの構造物は土槽壁面側に A-a とA-c，土槽中央部にA-b，Case Bの構造物は土槽壁面 側にB-aとB-c，土槽中央部にB-bの計6構造物を配置した。 模型地盤である豊浦砂層の層厚は300mmであり，排水壁 の壁厚は $t_{\mathrm{w}}=40 \mathrm{~mm}$ ，壁長は $L_{\mathrm{w}}=150 \mathrm{~mm} ，$ 構造物から壁体 までの距離は $d_{\mathrm{s}}=30 \mathrm{~mm}$ とした。

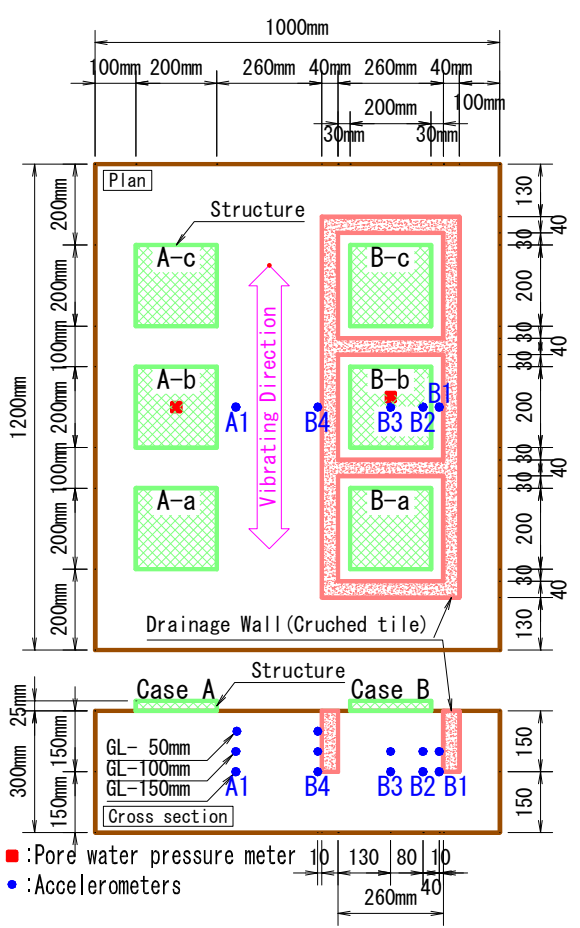

図-3 実験概要図

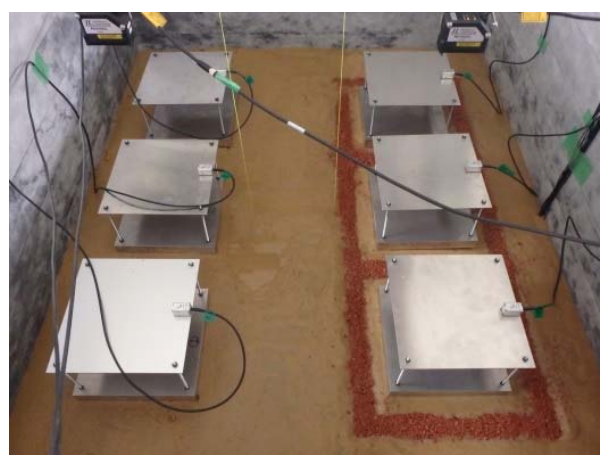

図-4 実験状況

ここで，本実験は重力場で行われ豊浦砂層は締固めを 伴わない水中落下方式による相対密度 $\mathrm{Dr}=22.8 \%$ の緩い 飽和地盤であるため, 地盤剛性は実地盤に比べて非常に 小さい，よって，本実験では排水壁の剛性が周囲の地盤 に比べて極端に大きくならないように，また，排水壁作 
成時に周囲の緩い地盤に影響を与えないようにするため, 破砕瓦による排水壁も締固めを伴わない水中落下法によ

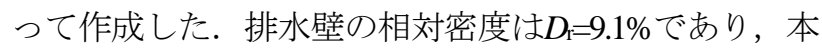
実験では壁体の剛性よりも水圧消散効果に期待している. 計測機器として加速度計を図-3に示寸構造物A-b，B-b の上部に設置し，間隙水圧計を未改良部（A1），排水 壁内部に壁面から格子中央部に向かって $10 \mathrm{~mm}, 50 \mathrm{~mm}$,

130mmの位置（B1〜B3），排水壁外部の壁面から $10 \mathrm{~mm}$ の位置（B4）に設置した．間隙水圧計の設置深度は上 部に構造物が無い計測地点となるA1やB4ではGL-50mm, GL-100mm, GL-150mmの3深度とし，構造物直下の計測 地点となるB1〜B3ではGL-100mm, GL-150mmの2深度と した．また，加速度計を設置した構造物 A-b，B-bについ てはレーザー変位計で沈下量を計測している.

図-5に入力波を示す. 本実験で用いた空圧振動台実験 装置は空圧アクチュエーターを用いるため緻密な制御を 苦手としている. そのため, 本実験で用いた入力は過去 の検証により波形が比較的安定していた周波数 $4 \mathrm{~Hz}$, 加 速度 $2.0 \mathrm{~m} / \mathrm{s}^{2}$ 程度の正弦波とした。加振時間は対策効果を 明確にするために比較的長い30秒とした.

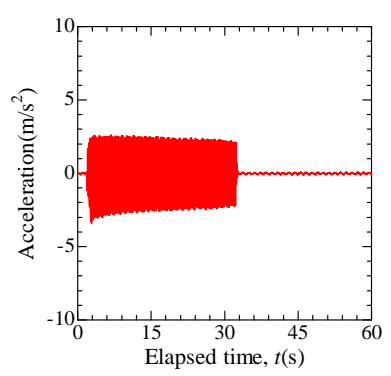

図-5 入力波

\section{(3) 実験結果}

図-6に過剩間隙水圧比を示す．ここで， $d_{w}$ は排水壁か らセンサーまでの水平距離を示す. 排水壁格子内のB1 〜B3, および排水壁近傍のB4の全深度において, 加振 直後に過剩間隙水圧比が1.0付近まで上昇し液状化に至 っているものの, その直後に加振中においても過剩間隙 水圧比が 0.7 程度まで減少していることがわかる．特に 排水壁に近いB1やB4においてはその効果が大きい。 こ こで, 排水壁内部や近傍において加振途中に過剩間隙水 圧比が1.0を上回っているのは排水壁による急激な排水 が地盤の剛性回復に強く影響を与えているためだと考え られる．また，加振後において過剩間隙水圧比が 0.0 ま で戻っていないのは液状化によってセンサーが沈み込み 静水圧の大きさが変わったためだと考えられる. また, 未対策であるA1においては加振が終了した32秒以降に おいても全深度で過剩間隙水圧が数秒間保持されている が, 液状化対策を行ったB1〜B4においては加振終了直 後から過剩間隙水圧の消散が始まっている.
図-7(a)にGL-150mmからGL-100mmに向けての鉛直動水 勾配，図-7(b)にGL-100mmにおける格子中央部から壁体 部に向けての水平動水勾配を示寸. 排水壁からの距離 $d_{w}$ が小さく排水壁に近いほど動水勾配の水平成分が大きく なる傾向にある．特に排水壁近傍では水平動水勾配が鉿 直動水勾配よりも大きくなり，相対的に鉛直方向よりも 水平方向の流れが卓越していることが確認できる.

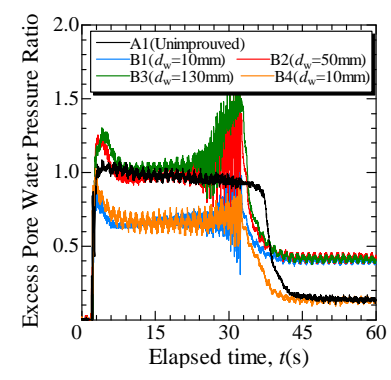

(a) GL-100mm

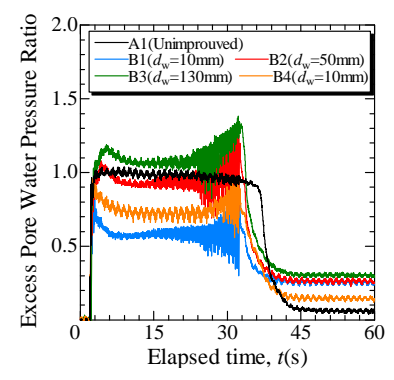

(b) GL-150mm
図-6 過剩間隙水圧比

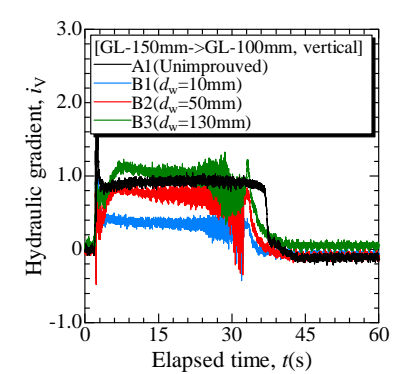

(a)鉛直方向

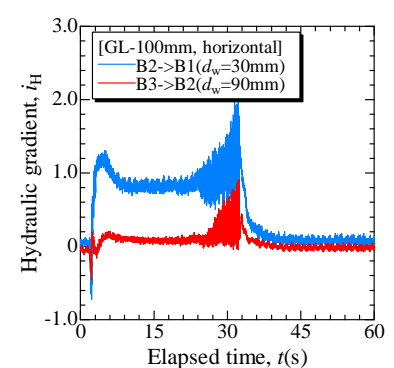

(b) 水平方向
図-7 動水勾配

図-8(a)に構造物の応答加速度を示寸. 地中連続排水壁 による液状化対策を行った構造物B-bにおける応答加速 度は入力加速度に比べて十分小さく, 未対策である構造 物A-bに比べて応答加速度の増加はわずかであることが わかる. 図-8(b)に構造物の鉛直変位量を示す. 加振開始 直後に両者ともにほぼ同様の沈下挙動を示しているが, 加振の途中から構造物B-bの沈下速度は大幅に減少し, 最終的な沈下量も小さい結果となった. 構造物の地盤へ のめり込み沈下量は構造物A-bが67.4mmで構造物B-bが $19.5 \mathrm{~mm}$ ，構造物の傾斜量は構造物A-bが46/1000で構造物 B-bが4/1000であり, 構造物B-bにおける沈下速度が減少 するタイミングと過剩間隙水圧比が減少するタイミング はほぼ同じであることがわかる. よって, 地中連続排水 壁は過剩間隙水圧を早期に消散させ, 構造物の沈下量や 傾斜量を大きく抑制可能であることを示している.

図-9に加振後における地盤内部の状況を示す．カラー サンドの設置深度はGL-100mmであり, 図中右側に示す 未対策であるCase Aでは構造物の沈下によって地盤内が 大きく変形していることが確認できるが, 図中左側に示 すCase Bでは排水壁に近い部分や排水壁内部においてあ 
まり地盤内が変形していない. これは, 過剩間隙水圧を 早期に消散し, 排水壁の岡性が周囲の地盤より高くせん 断変形を抑制した結果であると考えられる.

ここで, 周囲の地盤が完全に液状化した場合には排水 壁が自立できずに崩壊することも考えられたが，構造物 の沈下に伴い排水壁には若干の変形が生じているものの, 崩壊には至っていないことが確認できる。これは，排水 壁周辺の地盤における剛性回復と排水壁に向かう浸透流 によるものであると考えられる.つまり，排水壁周囲の 地盤では排水壁によって過剩間隙水圧が消散して剛性が 回復し，剛性が回復した地盤は逆に排水壁を支えるとい う互いに支えあう現象が生じていると考えられる.さら に排水壁付近では排水壁自身に向かって浸透圧が作用す るため，排水壁は水を吸うことによって自身の土圧を軽 減して崩壊を妨げていると考えられる.

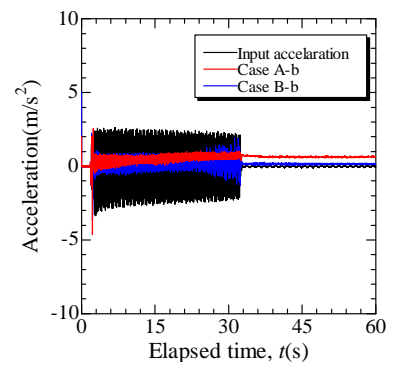

(a)応答加速度

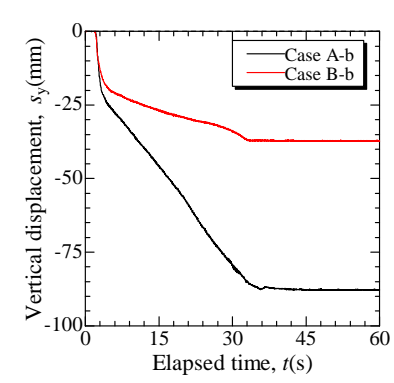

(b)鉛直変位量
図-8 構造物の応答加速度と鉛直変位量

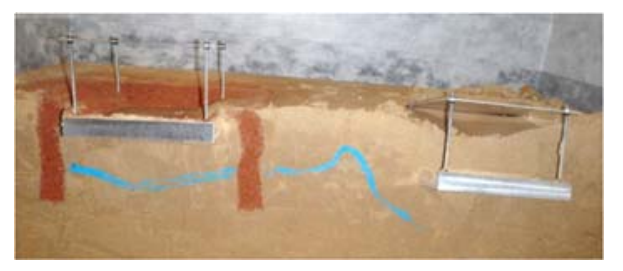

図-9 加振後における地盤内部の状況

\section{3. 有限要素法による検討}

\section{(1) 解析モデル}

解析はZhang et al.が提案している回転硬化型弾塑性構 成式Cyclic mobility model ${ }^{11)}$ による土水連成有限要素解析プ ログラム「DBLEAVES 」22)を用いる。このモデルは，土の 力学挙動に大きな影響を与える土の密度や過圧密比, 自 然堆積過程に形成された構造, および各種応力履歴を受 けることで発生した土の応力誘導異方性を同一モデル, 同一パラメータで表現することを目的に開発された構成 式である. Zhang etal.はHashiguchietal.が提案する下負荷面 13)，及びAsaoka et al.が提案する上負荷面 ${ }^{14}$ の概念に基づき， 図-10に示寸平均主応力 $p$ 軸差応力 $q$ 面上での新たな降 伏曲面を提案した。 このモデルでは限界状態線の勾配 $M$ が異方性の発展によらず一定となり, 楕円形の降伏曲面
の扁平率は応力状態や異方性の大きさに依存して変化す ることを特徵とする.ここで，回転軸らはせん断履歴に より, 静水圧軸である $p$ 軸から $\zeta_{1} ， \zeta 2$ 一変化する.

Cyclic mobility model $の$ 特徵を以下にまとめる.

1) 8個のパラメータの内，5個のパラメータはCam-clay model と同様であり, パラメータが比較的少ない.

2) 限界状態線は応力経路に因らず不変である.

3) 同一モデル，材料パラメータにて緩い砂におけるサ イクリックモビリティを伴わない液状化現象や中密 の砂におけるサイクリックモビリティを伴った液状 化現象が表現可能である.

4) 過剩間隙水圧消散後でも応力誘導異方性が保持され るため, 余震による再液状化現象が表現できる.

5）応力誘導異方性の発達の速度は, 砂質土のサイクリ ックモビリティ発生までの繰返し回数に影響を及ぼ し, 異方性の発達の速度が速ければ速いほど, 土の サイクリックモビリティがより起きやすくなる.

このモデルの降伏関数，およびを適合条件式を式(1) 〜(10)に示す.ここで， $p_{0}{ }^{*}$ は初期基準状態での $p_{\mathrm{m}}{ }^{*} ， S_{\mathrm{j}}$ は 偏差応力テンソル， $\beta_{\mathrm{j}}$ は異方性応力テンソルである.

応力誘導異方性テンソルの発展則 $d \beta_{\mathrm{i}}$ は異方性応力比 $\zeta$ が限界状態線の勾配 $M$ を回らないよう, 式(11)のよう に定式化される．ここで，式中のb 発展速度である $d \beta_{\mathrm{ij}}$ の大きさをコントロールするパラメ ータである. 構造喪失の発展則については, Asaoka et al が合理的な構造喪失の発展則 ${ }^{14)}$ を提案しており, その概 念をそのまま利用する，ただし，異方性の影響を考慮す る必要があるため, 構造喪失の発展則 $d R^{*}$ は式(12) のよ うになる。ここで, 式中の $a$ は構造 $R *$ 塸失速度である $d R^{*}$ の大きさをコントロールするパラメータである. 過 圧密の発展側については, 塑性ストレッチングテンソル と応力誘導異方性の二つの要因によってコントロールし ている. 過圧密の発展則 $d R$ は式(13)で表される.ここで, $m$ は過圧密の解消速度である $d R$ のきさコントロールす るパラメータである. 本解析で用いる地盤の透水係数は 透水試験で得られた実測值を使用しており，排水性材料 の透水係数は周囲の地盤の数倍〜10倍程度である. また， ウェルレジスタンス等は考慮していない.

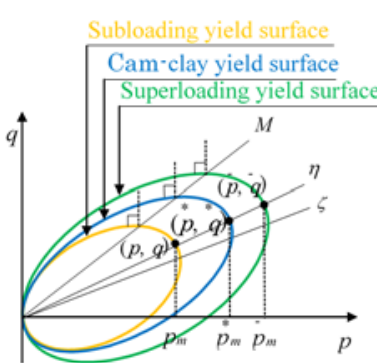

(a) 降伏曲面

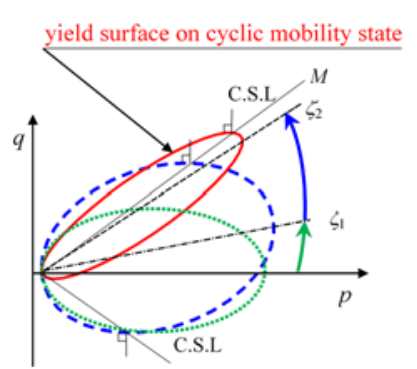

(b) 降伏曲面の変化
図-10 Cyclic mobility model $の$ 降伏曲面 


$$
\begin{aligned}
& f=\ln \frac{p}{p_{0}^{*}}+\ln \frac{M^{2}-\zeta^{2}+\eta^{* 2}}{M^{2}-\zeta^{2}}+\ln R^{*}-\ln R-\frac{\varepsilon_{\mathrm{v}}^{\mathrm{p}}}{C_{\mathrm{p}}}=0 \\
& d f=\frac{\partial f}{\partial \sigma_{i j}} d \sigma_{i j}+\frac{\partial f}{\partial \beta_{i j}} d \beta_{i j}+\frac{1}{R^{*}} d R^{*}-\frac{1}{R} d R-\frac{1}{C_{\mathrm{p}}} d \varepsilon_{\mathrm{v}}^{\mathrm{p}}=0 \\
& p=\frac{1}{3} \sigma_{\text {ii }} \\
& \eta^{*}=\sqrt{\frac{3}{2} \hat{\eta}_{i j} \hat{\eta}_{i j}} \\
& \hat{\eta}_{i j}=\eta_{i j}-\beta_{i j} \\
& \eta_{i j}=\frac{S_{i j}}{p}=\frac{\sigma_{i j}-p \cdot \delta_{i j}}{p} \\
& \eta=\sqrt{\frac{3}{2} \eta_{i j} \eta_{i j}} \\
& \zeta=\sqrt{\frac{3}{2} \beta_{i j} \beta_{i j}} \\
& C_{\mathrm{p}}=\frac{\lambda-\kappa}{1+e_{0}} \\
& \left\{\begin{array} { l } 
{ p = R \overline { p } } \\
{ q = R \overline { q } }
\end{array} \quad \left\{\begin{array}{l}
p^{*}=R^{*} \bar{p} \\
q^{*}=R^{*} \bar{q}
\end{array}\right.\right. \\
& d \beta_{i j}=\Lambda \frac{\sqrt{6} M b_{\mathrm{r}}(M-\zeta) \hat{\eta}_{i j}}{C_{\mathrm{p}}\left(M^{2}-\zeta^{2}+\eta^{* 2}\right) p} \\
& d R^{*}=\Lambda \frac{2 a M R^{*}\left(1-R^{*}\right) \eta^{*}}{C_{\mathrm{p}}\left(M^{2}-\zeta^{2}+\eta^{* 2}\right) p} \\
& d R=\Lambda \frac{-m \cdot M \ln R \sqrt{6 \eta^{* 2}+\frac{1}{3}\left(M^{2}-\eta^{2}\right)^{2}}}{C_{\mathrm{p}}\left(M^{2}-\zeta^{2}+\eta^{* 2}\right) p}\left\{\frac{\left(p / p_{0}\right)^{2}}{\left(p / p_{0}\right)^{2}+1}\right\}^{2} \\
& +R \frac{\eta}{M} \frac{\partial f}{\partial \beta_{i j}} d \beta_{i j}
\end{aligned}
$$

\section{(2) 要素試験による破砕瓦の材料パラメータの確定}

表-1に材料パラメータ，表-2に状態パラメータを示す。 これらは三軸試験等によって決定され, 豊浦砂のパラメ 一タは既往研究15において確定された值を用いる。ここ で，本解析で用いるパラメータは密度の影響を受けない 独立した定数であり，密度が及ぼす影響は過圧密比の逆 数であるRによってのみ制御される. そのため, 異なる 相対密度の試料を用いた三軸試験によってパラメータは 設定されるが，有限要素法を用いた解析では対象地盤の 状態に適した状態パラメータが個別に設定される.

図-11に中密，および緩い試料を対象とした平均有効 応力 $p^{\prime}=98 \mathrm{kPa}$ 一定における排水三軸圧縮試験の要素シミ ユレーション結果，図-12に中密な試料を対象とした初 期平均有効応力 $p^{\prime}{ }^{\prime}=98 \mathrm{kPa}$, 繰返しせん断応力比 $q / 2 p^{\prime}{ }_{0}=0.20 \sim 0.25$, 載荷周波数 $f=0.01 \mathrm{~Hz}$ における非排水繰 返し三軸試験の要素シミュレーション結果を示寸。ここ で，表-2に示寸過圧密比（1/R0） は等方圧密試験から圧 縮指数 $\lambda$ と膨潤指数 $\kappa$ を決定し, 初期構造 $R_{0}^{*}$ を仮定して
三軸試験結果とのフィッティングにより決定した．要素 シミュレーションと三軸試験結果は概ね良い対応関係に あり, パラメータの值は妥当であると考えられる.

表-1 解析パラメータ

\begin{tabular}{l|c|c}
\hline \multicolumn{1}{c|}{ Analysis parameter } & Toyoura sand & Crushed tile \\
\hline Compression index $\lambda$ & 0.0500 & 0.0750 \\
Swelling index $\kappa$ & 0.0064 & 0.0150 \\
Stress ratio at critical state $M$ & 1.300 & 1.800 \\
Void ratio $e_{0}\left(p^{\prime}=98 \mathrm{kPa}\right.$ onN.C.L) & 0.870 & 1.400 \\
Poisson's ratio $v$ & 0.300 & 0.300 \\
Degradation parameter of & 0.01000 & 0.00003 \\
overconsolidation state $m$ & 0.50000 & 0.00100 \\
Degradation parameter of structure $a$ & 1.500 & 0.300 \\
Evolution parameter of anisotropy $b_{r}$ &
\end{tabular}

表-2＼cjkstart要素シミュレーションの状態パラメータ

\begin{tabular}{l|c|c}
\hline \multicolumn{1}{c|}{ State parameter } & Toyoura sand & Crushed tile \\
\hline Initial structure $R_{0}^{*}$ & 0.800 & 0.100 \\
Initial degree of overconsolidation $1 / R_{0}$ & $3303\left(D_{1}=64.5 \%\right)$ & $31\left(D_{1}=65.5 \%\right)$ \\
Initial anisotropy $\zeta_{0}$ & $84\left(D_{1}=23.4 \%\right)$ & $8.7\left(D_{1}=49.6 \%\right)$ \\
\hline
\end{tabular}

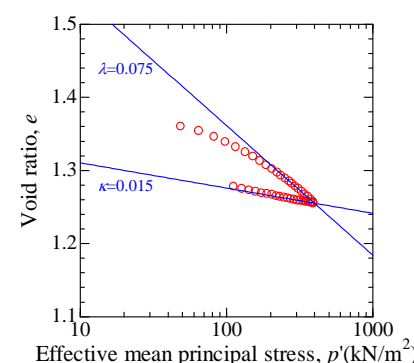

(a) 等方圧密試験

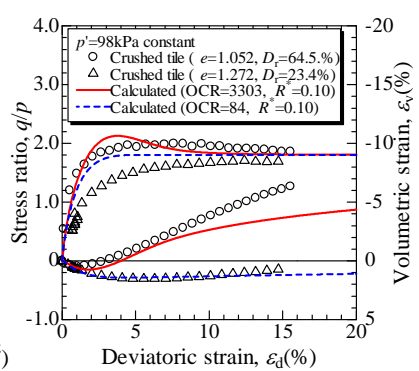

(b) 単調せん断試験
図-11 排水三軸圧縮試験（破砕瓦）
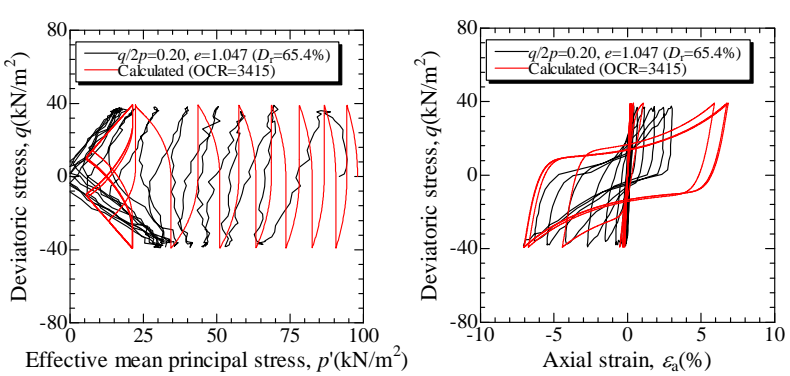

(a) 有効応力経路 $(q / 2 p=0.20)$
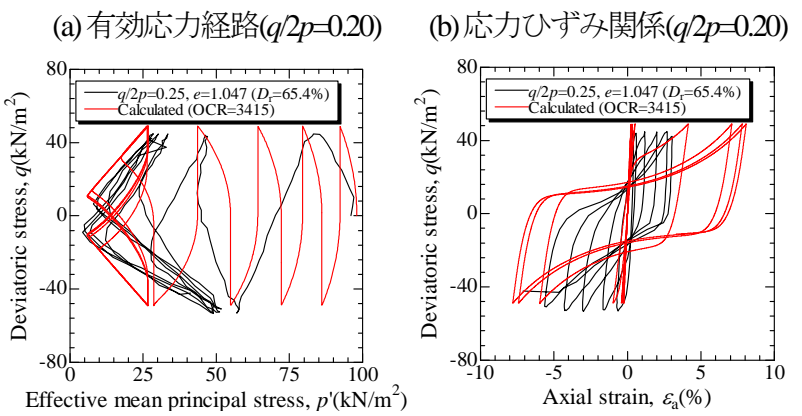

(a) 有効応力経路 $(q / 2 p=0.25)$

(b)応力ひずみ関倸 $(q / 2 p=0.25)$ 
（3） 3次元有限要素法による振動台実験の検証

\section{a) 解析条件}

図-13に解析メッシュを示寸. 本解析では幅 $1000 \mathrm{~mm}$, 奥行き $500 \mathrm{~mm}$, 高さ300mmの3次元半断面メッシュを用 いた.ここで，境界条件としてはメッシュ下端部におけ る全ての接点は $x, y, z$ 方向の固定境界，同一深度平面 の外周接点は全て等変位境界とし, 地下水位（排水境界 面）は振動台実験と同椂に地表面に設定している.

本検討における解析ケースは振動台実験と同様に未対 策地盤のCase A，破砕瓦を用いた地中連続排水壁による 液状化対策を行ったCase B（壁状改良），さらには振動 台実験は実施していないがCase Bの壁体内部に未改良部 を設けたCase C（柱状改良）についても検討を行った. ここで，Case Bは振動台実験と同様の排水壁で壁厚は $40 \mathrm{~mm}$ ，壁長は $150 \mathrm{~mm}$ ，排水壁と構造物との離隔は $30 \mathrm{~mm}$ であり，構造物の寸法や重量も実験と同様である. また, Case CはCase Bのような等厚壁ではなく，1辺が40mm， 改良体の基本間隔が40mmの柱状改良で，改良形状が対 策効果に及ぼす影響を検討している.

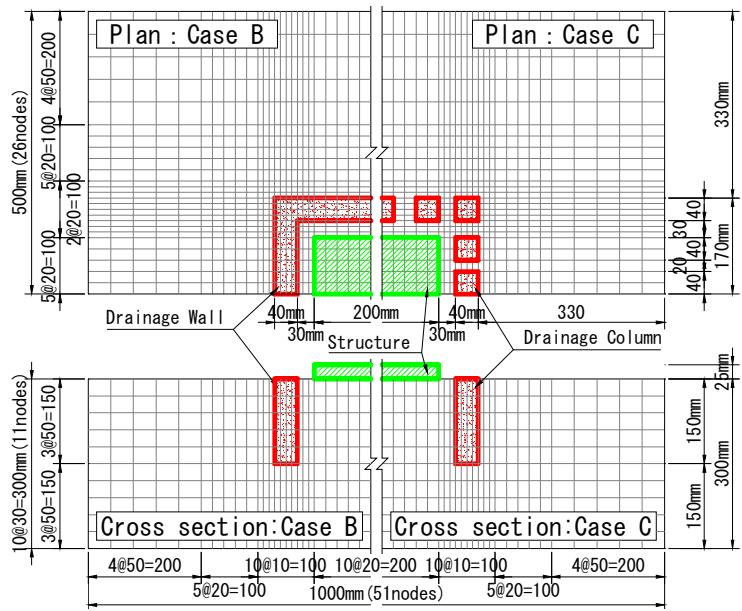

図-13 解析メッシュ (3次元解析)

本解析で用いた状態パラメータを表-3に示す，本解析 における湿潤単位体積重量や透水係数は振動台実験にお ける実測值を用いているが，計算を安定させるために相 対密度は実験よりも若干高めに設定した．初期構造は豊 浦砂が $R_{0}^{*}=0.80$, 破砕瓦が $R_{0}^{*}=0.10$, 初期異方性は両者共 に $\zeta_{0}=0$ と仮定している. その他の基本的なパラメータは 三軸試験より決定した表-1に示すパラメータを使用した. 入力波を図-14に示す. 入力波は振動台実験と同様に 周波数 $f=4 \mathrm{~Hz}$ の正弦波を1方向（図-13の左右方向）から 入力している. ただし, 振動台実験では最大加速度は $2.0 \mathrm{~m} / \mathrm{s}^{2}$ 程度，加振時間は30秒間であったが，本解析では 計算を安定させるために最大加速度は振動台実験の半分 である $1.0 \mathrm{~m} / \mathrm{s}^{2}$, 加振時間は振動台実験より20秒短い10秒 間とした. 本解析では加振後において解析プログラムや
パラメータを変えることなく静的圧密解析を連続的に行 っている. 本解析における時間増分は $\Delta t=0.005$ 的あり, 時間離散化には陰解法である Newmark $\beta$ 法を用いて $\beta=0.3025, \gamma=0.6$ として解析を行っている. また, 本解析 では初期剛性比例型のレリー減衰を使用しており, 減衰 係数は全地盤において $h=0.05$ ある.

表-3 3次元解析の状態パラメータ

\begin{tabular}{l|c|c}
\hline \multicolumn{1}{c|}{ State parameter } & Toyoura sand & Crushetile \\
\hline Permeability $k(\mathrm{~m} / \mathrm{s})$ & $1.29 * 10^{4}$ & $3.26^{*} 10^{-4}$ \\
wet unit weight $\chi\left(\mathrm{kN} / \mathrm{m}^{3}\right)$ & 18.39 & 16.29 \\
Initial structure $R_{0}^{*}$ & 0.800 & 0.100 \\
Initial degree of overconsolidation $1 / R_{0}$ & $9\left(D_{\mathrm{l}}=50 \%\right)$ & $904\left(D_{1}=50 \%\right)$ \\
Initial anisotropy $\zeta_{0}$ & 0.000 & 0.000 \\
\hline
\end{tabular}

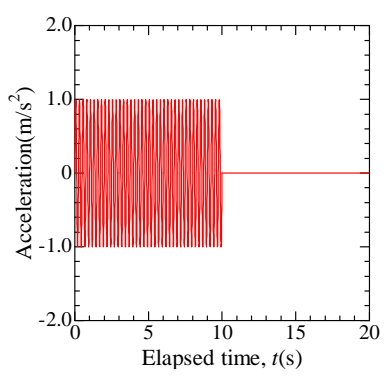

図-14 入力波（3次元解析）

\section{b) 解析結果}

本解析では振動台実験を対象にしているが，相対密度 や入力加速度などが実験とは異なるため, 各ケースにお いては定性的な比較を行う。また，以降に示寸解析結果 は全て半断面の対称軸である土層中央部における解析結 果である．図-15にGL-100mmにおける排水壁からの距離 $d_{w}(\mathrm{~mm})$ ごとの過剩間隙水圧比, Case Aにおける加振終了 直後の過剩間隙水圧比分布を示す．実験結果と同様に排 水壁近傍 $\left(d_{\mathrm{w}}=0 \mathrm{~mm}\right)$ では未対策であるCase Aに比心゙液 状化対策を行ったCase BやCase Cでは加振後にける過剩 間隙水圧の消散が早く, 柱状改良であるCase Cよりも壁 状改良であり改良率が高いCase Bの方が対策効果が大き いことがわかる．また，解析結果は実験結果と同様に排 水壁からの距離が大きくなると対策効果は小さくなるも のの, 排水壁中央部 $\left(d_{\mathrm{w}}=120 \mathrm{~mm}\right)$ においても過剩間隙 水圧の消散は若干早いことがわかる。ここで, $d_{w}=120 \mathrm{~mm}$ の位置において加振終了後において過剩間隙 水圧比が上昇している. これは, 図-15(c)から構造物下 部においては初期有効応力が高いため加振後の過剩間隙 水圧比が周囲の地盤より低く, 過剩間隙水圧比が高くな った周囲の地盤から水圧が伝搬するためだと考えられる.

図-16にGL-105mmからGL-45mmに向けての鉛直動水勾 配，図-17にGL-105mmにおける格子中央部から壁体部に 向けての水平動水勾配を示寸. 解析結果では, 構造物の 下部地盤において構造物重量によって初期有効応力が高 
いため実験結果とは異なり完全には液状化に至っていな いものの，鉛直動水勾配はCase B $<$ Case C $<$ Case Aであり， 水平動水勾配はCase A $<$ CaseC $<$ CaseB $B$ である.つまり， 解析結果においても実駼結果と同様に排水壁周辺では水 平方向に流れが発生している. また，過剩間隙水圧の消 散効果と同様に壁状改良のCase Bの方が柱状改良である CaseCよりも排水効果が高いと考えられる.

図-18に加振直後, および圧密終了後における壁体の 変位状況を示す．加振直後においては全ケース同様の変 位状況であるが，その後の圧密沈下により最終的には Case BはCase Cよりも変位が小さくなっており，わずか ではあるがCase Aが一番大きい. また，構造物の沈下に 伴い地表面に近い上部での変形量が大きいことがわかる.

図-19に改良体の変形が大きかった改良体上部である GL-15mm，およびGL-45mmにおける壁体要素のせん断 ひずみを示す，対象要素は図-19内に図示したように, 変形が大きい正面左内側の要素の地表面から1つ目

(GL-15mm) の要素と2つ目（GL-45mm）の要素である. 加振中や加振直後においては, Case Bの方がCase Cより も大きいが，図-18に示した変位量と同様に圧密終了後 における最終的なせん断ひずみはCase Bの壁状改良の方 がCaseCの柱状改良よりも小さい.

図-20に構造物の応答加速度と沈下量, 図-21に構造物 中心直下の地盤における体積ひずみと偏差ひずみを示す。 全ケースにおいて構造物の応答加速度はほぼ同程度であ り, 実験と同様に地中連続排水壁が構造物の応答加速度 に与える影響は小さい結果となった。 また, 最終沈下量 は未改良であるCaseAが30.6mm，CaseBが28.4mm，CaseC が28.9mmであり，Case Bで7.2\%，Case Cで5.6\%の沈下抑 制となった. ここで, 全ケースにおいて加振終了後に沈 下量が若干回復している，これは，図-21から加振後に 有効応力が回復し体積圧縮（圧密）が生じているものの, 偏差ひずみが減少することによって高さ方向に伸長側の ひずみ（三軸伸張状態）が発生したためだと考えられる。 構造物の傾斜量はCase Aの51/1000に対し, Case B とCase C は46/1000であり，両ケースとも $9.8 \% の$ 傾斜抑制となった。 本解析では計算を安定させるため実験条件とは異なっ た相対密度や入力加速度を用いて解析を行ったため, 解 析結果と実験結果を定量的に比較することは困難である. しかし, 解析結果は構造物周囲に構築された地中連続排 水壁による過剩間隙水圧の早期消散効果やそれに伴う構 造物の沈下抑制が可能であることを示しており, 解析結 果は定性的ではあるが実験結果と対応している.また， 今回の検討では限定的な条件ではあるがCase Cの柱状改 良よりCase Bの壁状改良の方が液状化対策効果は高い結 果となった. しかし, 壁状改良の優位性を断定するため には柱状改良の改良径や改良率, 配置方法などを変えた 様々な改良仕様における更なる検討が必要である.

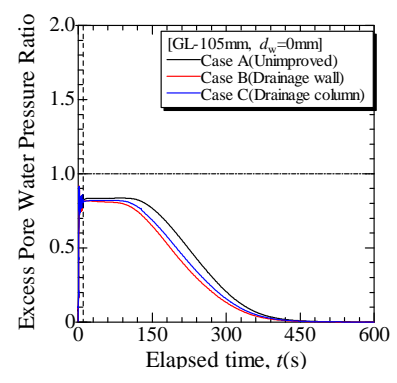

(a) $d_{\mathrm{w}}=0 \mathrm{~mm}, \mathrm{GL}-100 \mathrm{~mm}$

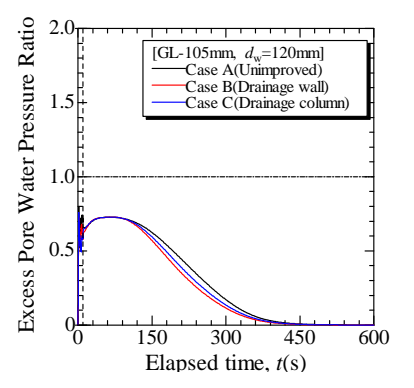

(b) $d_{\mathrm{w}}=120 \mathrm{~mm}, \mathrm{GL}-100 \mathrm{~mm}$

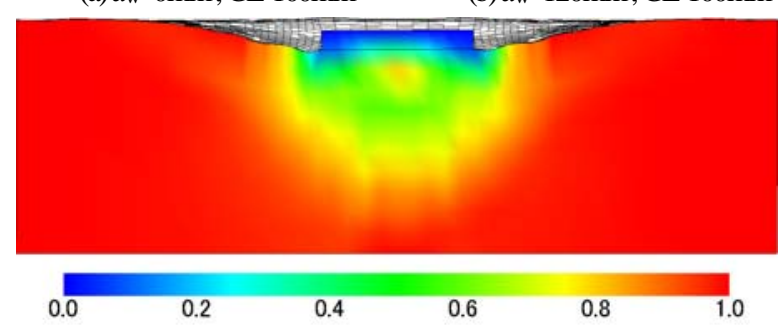

(c)Case Aにおける加振終了直後の過剰閒隙水圧比分布

図-15 過剰間隙水圧比

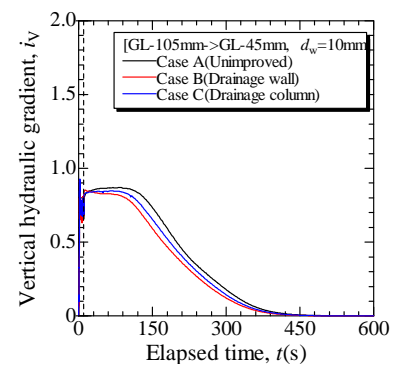

(a) $d_{w}=10 \mathrm{~mm}$

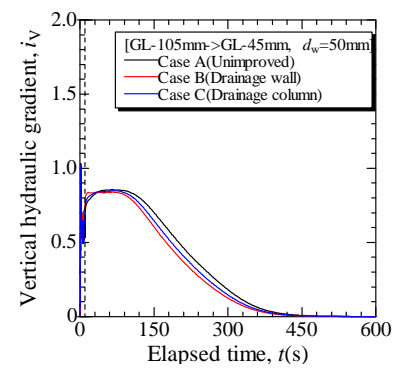

(b) $d_{\mathrm{w}}=50 \mathrm{~mm}$
図-16 鉛直動水勾配 (GL-105mm $\rightarrow \mathrm{GL}-45 \mathrm{~mm})$

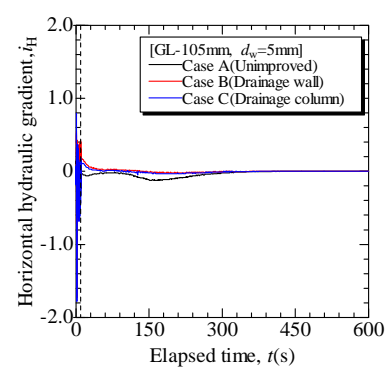

(a) $d_{w}=5 \mathrm{~mm}$

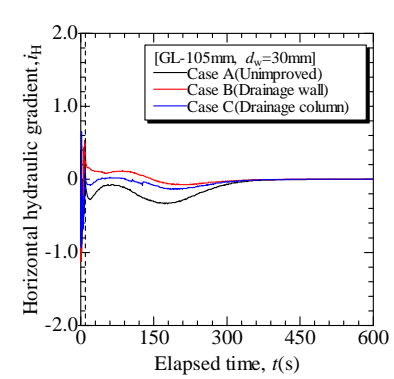

(b) $d_{\mathrm{w}}=30 \mathrm{~mm}$
図-17 水平動水勾配（GL-105mm）

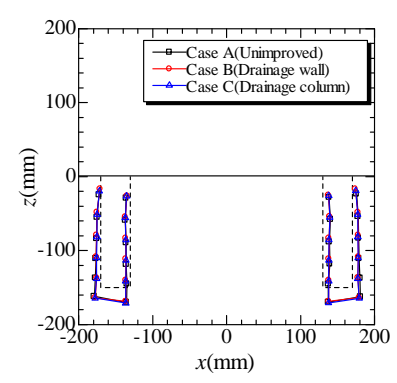

(a)加振直後

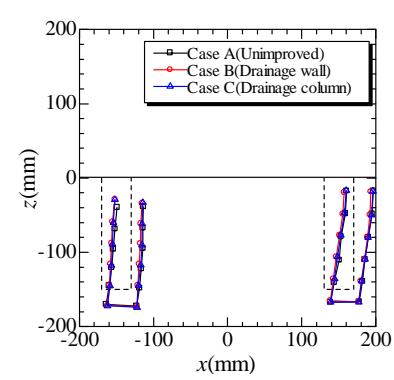

(b) 圧密終了後
図-18 壁体の変位状況 


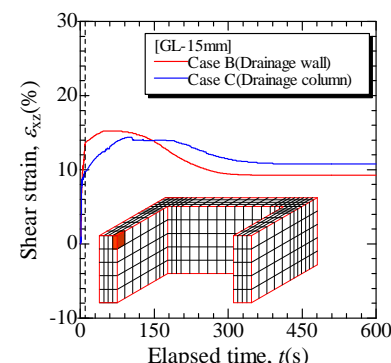

(a) GL-15mm

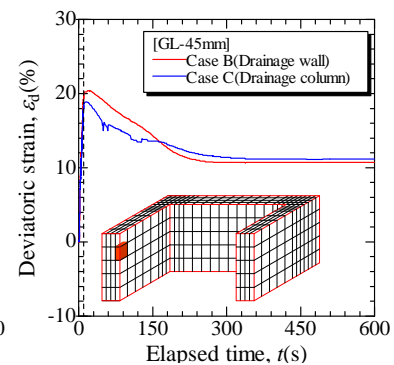

(b) GL-45mm
図-19 壁体の偏差ひずみ

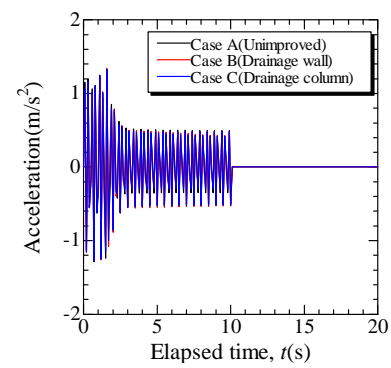

(a) 応答加速度

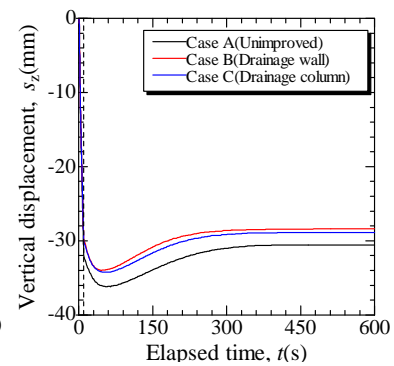

(b) 沈下量
図-20 構造物の応答加速度と沈下量

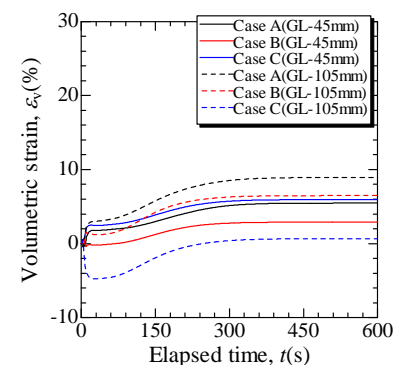

(a)体積ひずみ

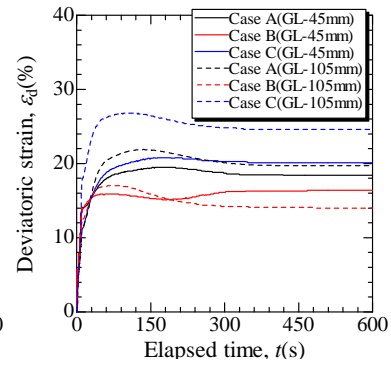

(b) 偏差ひずみ
図-21 構造物下部地盤における体積ひずみと偏差ひずみ

\section{（4） 2次元有限要素法による実スケール地盤での検討 a) 解析条件}

地中連続排水壁の壁体長や透水係数が構造物の沈下量 や傾斜量に及ぼす影響を検討するために2次元有限要素 法による実地盤スケールの解析を行った. 図-22に解析 メッシュと構造物寸法を示す。本解析では幅 $120 \mathrm{~m}$, 高 さ20mの範囲を対象とした．境界条件はメッシュ下端部 における全接点は $x, y$ 方向の固定境界，同一深度におけ る左右端部の接点は等変位境界とし，地下水位はGL$1.0 \mathrm{~m}$ 仮定した。本解析では振動台実験と同様に構造物 の自重による沈下，およびその抑制効果を確認するため 構造物は固有周期などを考慮していない幅 $6.0 \mathrm{~m} て ゙$ 設置圧 が19.6kN/m² となるブロック状のものとし，構造物が1つ の場合と構造物が2つの場合において解析を行った。ま た，構造物間の距離については3.0mと仮定した。

構造物が1つの場合の解析ケースを表-4に示す．構造 物が1つの場合の解析ケースは，未対策地盤のCase A, 破砕瓦による地中連続壁の壁体長が $L_{\mathrm{w}}=2.0 \mathrm{~m} の$ Case B,
$L_{\mathrm{w}}=4.0 \mathrm{~m} の$ Case C, $L_{\mathrm{w}}=8.0 \mathrm{~m} の$ Case Dの全4ケースとした.

構造物が2つの場合の解析ケースを表-5に示す。構造 構造物が2つの場合の解析ケースは，構造物が1つの場合 と同様のCase $\mathrm{A} \sim \mathrm{D}$ に加え壁体長が $L_{\mathrm{w}}=8.0 \mathrm{~m}$ で壁体の材料 にセメント改良土を想定した高剛性の弾性体（ $E=1.5 \mathrm{GPa})$ を用いたCase Eを追加した. さらに，上述した全ケース

（Case A〜E）についてセメント改良土による一般的な 地中連続壁のような難透水性の壁体 $\left(k_{\mathrm{w}}=1.5 \times 10^{-9} \mathrm{~m} / \mathrm{s}\right)$ を用いたケースについても解析を行い，壁体の排水性能 が沈下抑制に及ぼす影響についても検討を行っている.

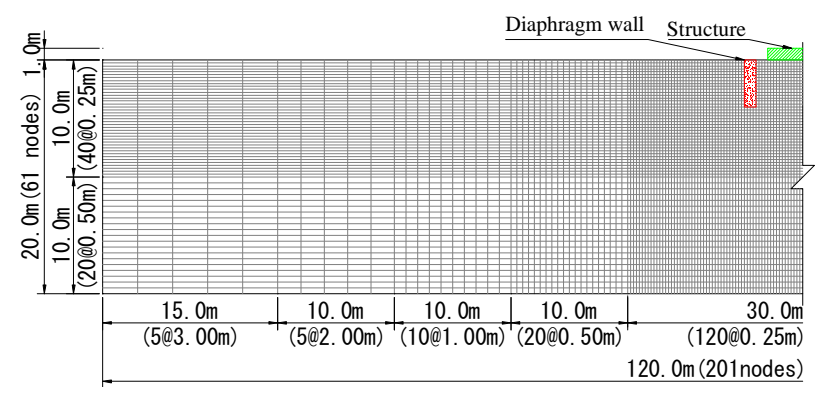

(a)解析メッシュ

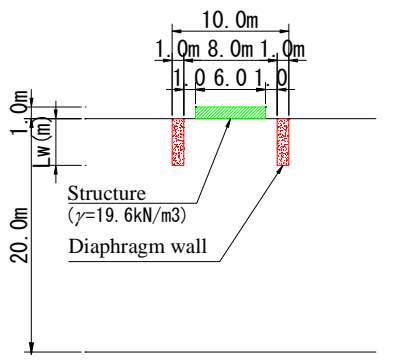

(b) 構造物 $\times 1$ のケース

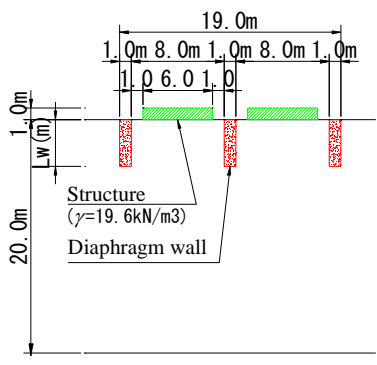

(c)構造物 $\times 2$ のケース
図-22 解析メッシュと構造物寸法（2次元解析）

表-4 構造物が1つの場合の解析ケース

\begin{tabular}{|c|c|c|c|}
\hline & $\begin{array}{c}\text { Material of } \\
\text { diaphragm wall }\end{array}$ & $\begin{array}{c}\text { Wall length } \\
L_{\mathrm{w}}(\mathrm{m})\end{array}$ & $\begin{array}{c}\text { Permeability } \\
k_{\mathrm{w}}(\mathrm{m} / \mathrm{s}) \\
\end{array}$ \\
\hline Case A & - & - & - \\
\hline Case B & \multirow{3}{*}{$\begin{array}{c}\text { Crushed tile } \\
\text { (Elastoplastic model) }\end{array}$} & 2.0 & $1.5 * 10^{-4}$ \\
\hline Case C & & 4.0 & $1.5 * 10^{4}$ \\
\hline Case D & & 8.0 & $1.5 * 10^{4}$ \\
\hline
\end{tabular}

表-5 構造物が2つの場合の解析ケース

\begin{tabular}{|c|c|c|c|}
\hline & $\begin{array}{c}\text { Material of } \\
\text { diaphragm wall }\end{array}$ & $\begin{array}{c}\text { Depth of Wall } \\
L_{\mathrm{w}}(\mathrm{m})\end{array}$ & $\begin{array}{c}\text { Permeability } \\
k_{\mathrm{w}}(\mathrm{m} / \mathrm{s})\end{array}$ \\
\hline Case A & - & - & - \\
\hline Case B1 & \multirow{6}{*}{$\begin{array}{c}\text { Crushed tile } \\
\text { (Elastoplastic model) }\end{array}$} & \multirow{2}{*}{2.0} & $1.5 * 10^{4}$ \\
\hline Case B2 & & & $1.5 * 10^{-9}$ \\
\hline Case C1 & & \multirow{2}{*}{4.0} & $1.5 * 10^{4}$ \\
\hline Case C2 & & & $1.5 * 10^{-9}$ \\
\hline Case D1 & & \multirow{4}{*}{8.0} & $1.5 * 10^{-4}$ \\
\hline Case D2 & & & $1.5 * 10^{-9}$ \\
\hline Case E1 & \multirow{2}{*}{$\begin{array}{l}\text { Improved soil } \\
\text { (Elastic model) }\end{array}$} & & $1.5 * 10^{-4}$ \\
\hline Case E2 & & & $1.5 * 10^{-9}$ \\
\hline
\end{tabular}


表-6に状態パラメータを示す. 本解析では地盤材料に は豊浦砂，地中連続壁には破砕瓦の解析パラメータを用 いているが，実地盤を想定しているため非常に緩い状態 ではなく豊浦砂の相対密度は $D_{1}=75 \%$ （締固め度 : 95\%）， 破砕瓦の相対密度は $D_{1}=95 \%$ （締固め度 : 99\%）と仮定し た. 地中連続排水壁の材料である破砕瓦の透水係数は実 測値とほぼ同様の $k=1.50 \times 10^{-4} \mathrm{~m} / \mathrm{s}$ とした。 ここで，原地 盤の透水係数は豊浦砂の透水係数では高すぎるため, 本 解析では液状化被害の大きい細砂程度の透水係数となる ように地中連続排水壁の $1 / 10$ となる $k=1.50 \times 10^{-5} \mathrm{~m} / \mathrm{s}$ と仮定 した. 初期構造等のパラメータは前述した振動台実験の 再現解析と同様に豊浦砂が $R_{0}^{*}=0.80$, 破砕瓦は $R_{0}^{*}=0.10$ と 仮定し，初期異方性は両者共に $\zeta_{0}=0$ としている.

入力波を図-23に示寸. 入力波は東北地方太平洋沖地 震の本震（2011年3月11日14時46分）においてKik-net下総

（千葉県, 設置深度2300m) で観測されたN-S方向の地 震動であり，時間増分は $\Delta t=0.01 \mathrm{~s} て ゙$ 解析を行った。また， 加振後においては上述した3次元解析と同様に同一モデ ル, 同一パラメータによる連続的な静的圧密を行った.

表-6 2次元解析の状態パラメータ

\begin{tabular}{l|c|c}
\hline \multicolumn{1}{c|}{ State parameter } & Original ground & Diaphragm wall \\
\hline Permeability $k(\mathrm{~m} / \mathrm{s})$ & $1.50 * 10^{-5}$ & $1.50^{*} 10^{4}$ \\
& 19.31 & $\left(1.50^{*} 10^{-9}\right)$ \\
wet unit weight $\gamma\left(\mathrm{kN} / \mathrm{m}^{3}\right)$ & 0.800 & 17.87 \\
Initial structure $R_{0}^{*}$ & $66\left(D_{\mathrm{h}}=75 \%\right)$ & 0.100 \\
Initial degree of overconsolidation $1 / R_{0}$ & 0.000 & 0.000 \\
Initial anisotropy $\zeta_{0}$ & \multicolumn{2}{|c}{} \\
\hline
\end{tabular}

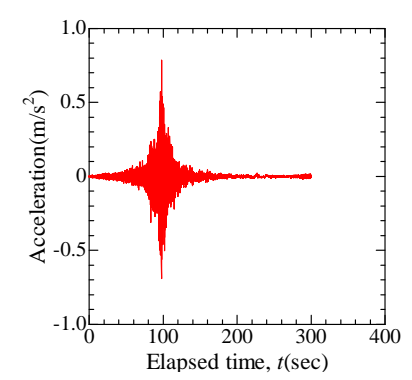

図-23 入力波 (2次元解析)

\section{b) 解析結果 (構造物 $\times 1)$}

図-24にGL-4.0mにおける過剩間隙水圧比を示寸．加振 直後においては各ケースに大きな差は確認できないが, 加振後の圧密過程において各ケースに差が生じているこ とがわかる. 特に排水壁近傍では改良効果が大きく, 排 水壁の下端が計測地点と同深度であるCase C $\left(L_{\mathrm{w}}=4.0 \mathrm{~m}\right)$ や排水壁深度が計測地点より深いCaseD $\left(L_{\mathrm{w}}=8.0 \mathrm{~m}\right)$ にお いては未対策のCase Aに比べて過剩間隙水圧の消散時間 が大幅に短縮できている．また，排水壁からの距離が最 も大きい構造物中心直下 $\left(d_{\mathrm{w}}=4.0 \mathrm{~m}\right)$ においても過剰間 隙水圧が早期に消散していることが確認できる.

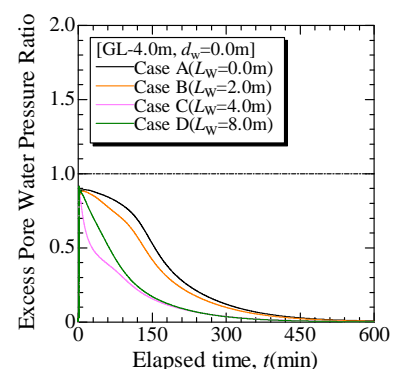

(a)壁体から $0.0 \mathrm{~m}$

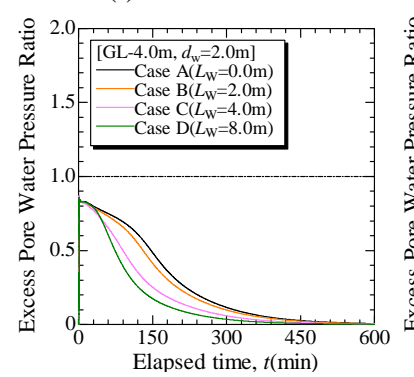

(c)壁体力八 $2.0 \mathrm{~m}$

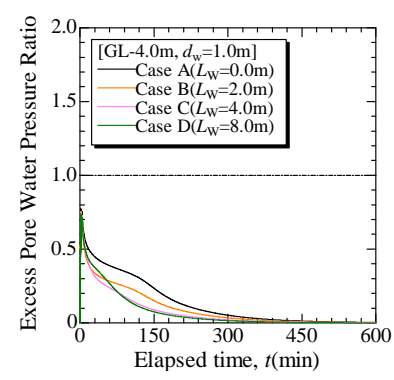

(b)壁体から $1.0 \mathrm{~m}$

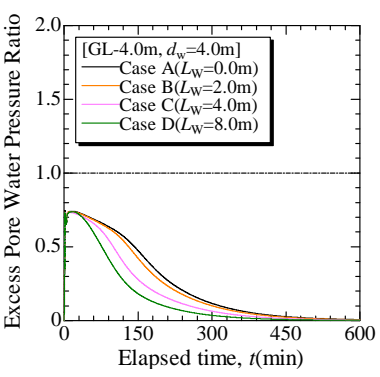

(d) 壁体から $4.0 \mathrm{~m}$
図-24 過剩間隙水圧比（GL-4.0m）

図-25にGL-4.0mからGL-2.0mに向けての鉛直動水勾配 を示寸．排水壁の近傍では排水壁の影響が強く, 圧密過 程において各ケースで大きな差が生じている．特に計測 地点の直上が排水壁の下端部であるCase Bにおいては鉛 直動水勾配が最も大きくなっているが，排水壁から離れ るにつれて各ケースにおける差は小さくなっている.

図-26に GL-4.0m における格子中央部から壁体部に向 けての水平動水勾配を示す. 未改良である Case A と同様 に計測地点が排水壁下端より $2.0 \mathrm{~m}$ 下方となる Case B に おいては, 排水壁の影響も少なく水平動水勾配はほとん ど発生していないことがわかる，一方で，排水壁の下端 が計測地点と同深度である CaseCや排水壁深度が計測地 点より深い Case D においては, 壁体からの距離が $d_{\mathrm{w}}=1.50 \mathrm{~m}$ 程度までは大きな水平動水勾配が発生しており, 鉛直動水勾配，水平動水勾配ともに排水壁からの距離が $d_{\mathrm{w}}=2.50 \mathrm{~m}$ 以上になると排水壁による影響は小さくなる. よって, 解析結果は実験結果と同様に排水壁近傍では排 水壁に向かった浸透流が発生していると考えられる.

図-27に構造物の応答加速度と鉛直変位量を示寸. 全 ケースとも応答加速度はほぼ同様であり, 本解析におい ても排水壁が構造物の応答加速度に与える影響は小さい. また, 各ケースにおける圧密終了後の沈下量はCase Aが 0.584m，CaseBが0.562m，CaseCが0.554m，CaseDが0.542m であり，未改良であるCase Aに比べてCase Bが4\%, Case Cが5\%, Case Dが7\%程度沈下量を抑制できた. 上述した ように排水壁から $4.0 \mathrm{~m}$ 離れた構造物中心部においても液 状化後における過剩間隙水圧の消散が早くなるため, 過 剩間隙水圧比々同様に壁体長が長くなるほど対策効果は 大きくなっている，しかし，地上構造物の液状化被害は 構造物の沈下量よりも不等沈下による傾斜量の方が問題 
となるため，次項において近接構造物の相互作用によっ て不等沈下が発生するケースについても検討を行う。

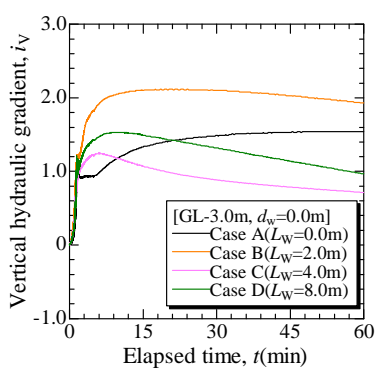

(a)壁体から $0.0 \mathrm{~m}$

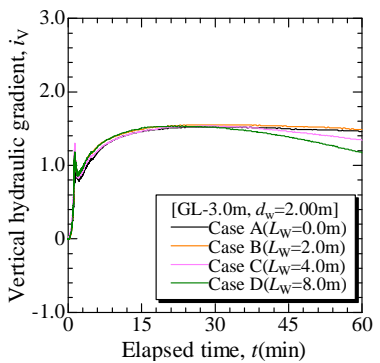

(c)壁体から $2.0 \mathrm{~m}$

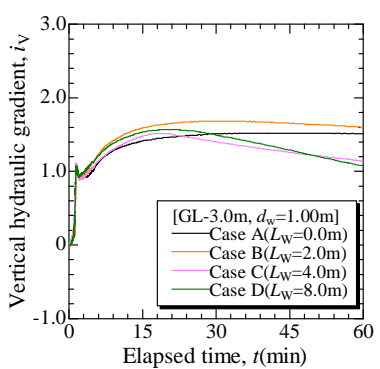

(b)壁体加 $1.0 \mathrm{~m}$

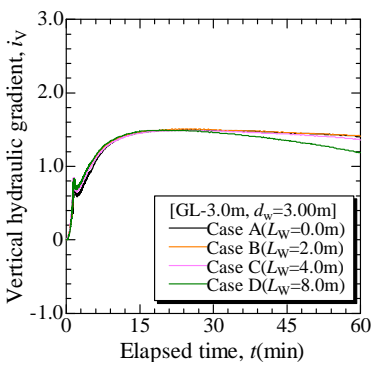

(b)壁体から $3.0 \mathrm{~m}$
図-25＼cjkstart鉛直動水勾配（GL-4.0m $\rightarrow \mathrm{GL}-2.0 \mathrm{~m} ）$

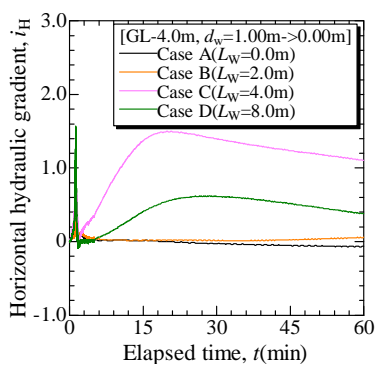

(a)壁体から $0.5 \mathrm{~m}$

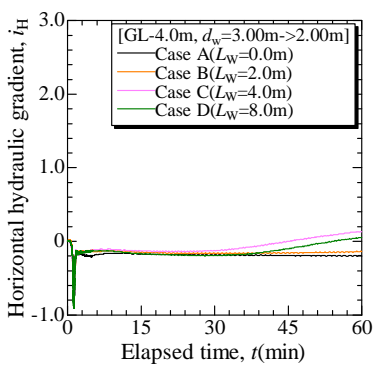

(c)壁体から $2.5 \mathrm{~m}$

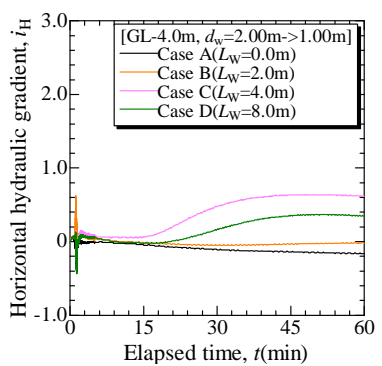

(b) 壁体から $1.5 \mathrm{~m}$

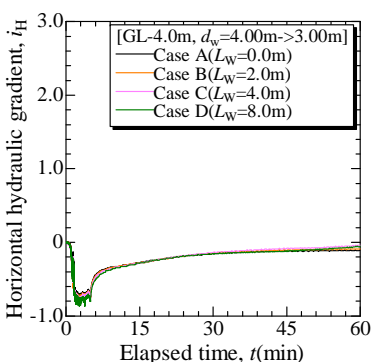

(b) 壁体から $3.5 \mathrm{~m}$
図-26 水平動水公配 (GL-4.0m)

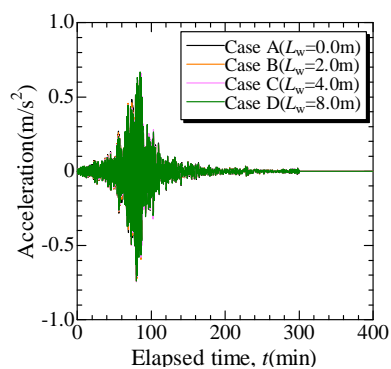

(a) 応答加速度

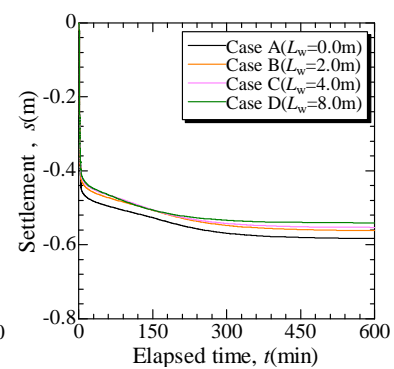

(b) 沈下量 図-27＼cjkstart構造物の応答加速度と沈下量

\section{c) 解析結果 (構造物 $\times 2)$}

本章では難透水性材料やセメント改良土を想定した高 強度な弾性体を用いたケースついても検討を行った。

図-28〜31 に GL-4.0m における過剩間隙水圧比を示 す．加振中においては全ケースに大きな差は確認できな い. しかし，排水性の高い地中連続壁のケースでは加振 終了後の過剩間隙水圧が早期に消散しており，壁体長が 長いほど改良効果が高いことが確認できる．また，剛性 と排水性の両方が高い地中連続壁を用いたケース（Case E1）においては，特に改良効果が高い結果となった。 ここで，弾性体を用いた CaseE1の夕排水壁内部の過剰 間隙水圧比が低くなっているのは，壁体の透水係数が高 い上にせん断に伴う体積変化が発生しないためであると 考えられる. 一方で，難透水性材料を用いたケースで は，弾性体材料を用いた Case E2 を含め加振時や加振後 の圧密過程においてもあまり効果が確認できず，構造物 中心直下である $d_{\mathrm{w}}=4.0 \mathrm{~m}$ においては未対策である Case A とほぼ同様の挙動を示している。

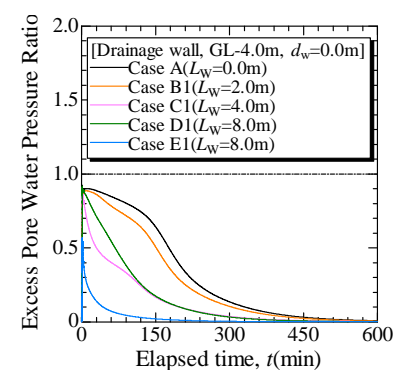

(a)排水壁

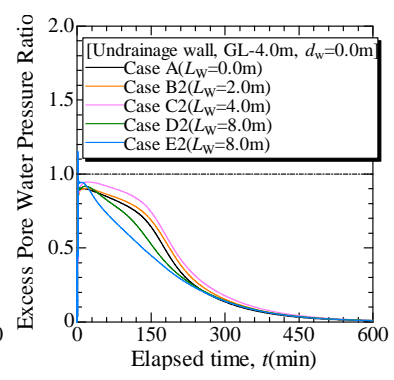

(b) 難透水壁
図-28 過剩間隙水圧比 $\left(\mathrm{GL}-4.0 \mathrm{~m}, d_{\mathrm{w}}=0.0 \mathrm{~m}\right)$

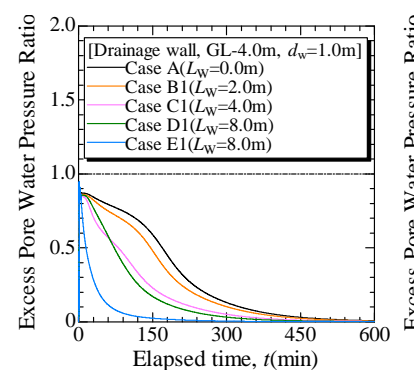

(a) 排水壁

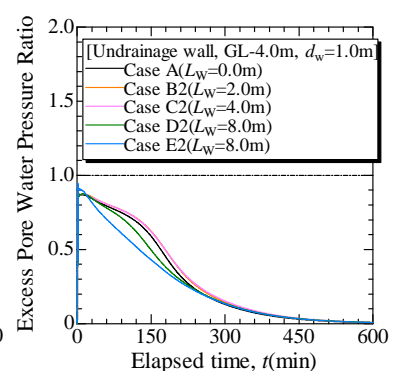

(b) 難透水壁
図-29 過剩間隙水圧比 $\left(\mathrm{GL}-4.0 \mathrm{~m}, d_{\mathrm{w}}=1.0 \mathrm{~m}\right)$

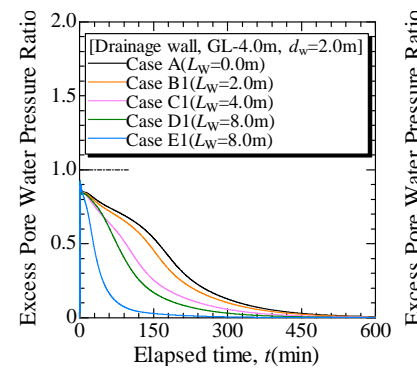

(a)排水壁

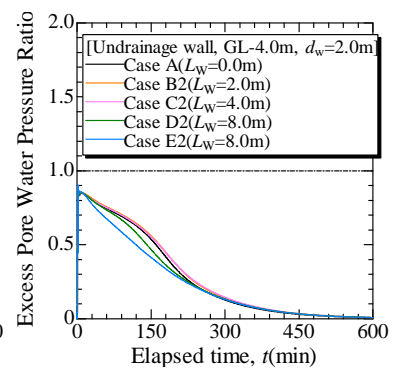

(b) 難透水壁
図-30 過剰閒隙水圧比 $\left(G L-4.0 m, d_{\mathrm{w}}=2.0 \mathrm{~m}\right)$ 


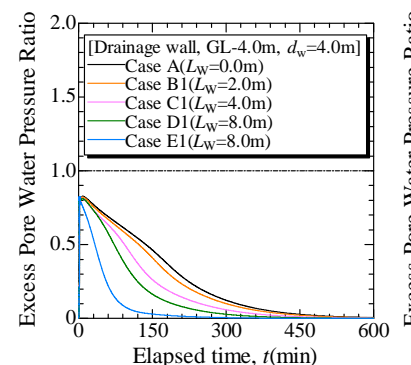

(c) 排水壁【加振後】

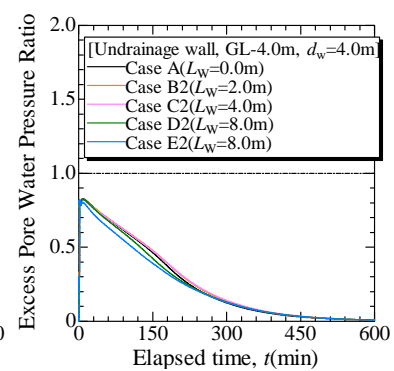

(d) 難透水壁【加振後】
図-31 過剰間隙水圧比 $\left(G L-4.0 \mathrm{~m}, d_{\mathrm{w}}=4.0 \mathrm{~m}\right)$

図-32 に構造物の沈下量, 図-33に構造物の傾斜量, 表-7 に最終沈下量と最終傾斜量のまとめを示寸. 上述 したとおり，加振中や加振直後における過剩間隙水圧比 においては各ケースに大きな差は確認できなかったが, 構造物の沈下量や傾斜量には大きな差が生じている.こ れは，地中連続壁によって地盤が拘束されたためと考え られる。ここで，限定的ではあるが本解析における条件 においては，地中連続壁に難透水性材料を用いたケース では最大で $4 \%$ 程度, 排水性の高い地盤材料を用いたケ 一スでは最大で $6 \%$, 排水性の高い高強度な弾性体材料 を用いたケースでは 13\%程度沈下量を抑制している。一 方で，構造物の傾斜量を見ると，難透水性の地盤材料を 用いたケースでは最大で $24 \%$, 難透水性の高強度な弾性 体を用いたケースでは 43\%程度傾斜量を抑制している. さらに，排水性の高い地盤材料を用いたケースでは最大 で 38\%，排水性の高い高強度な弹性体材料を用いたケ 一スでは 61\%も傾斜量を抑制している.

以上の結果より，地中連続壁による液状化対策を行っ た場合, 特に傾斜量においては各ケースの差は著しく改 良効果も高いことから，地中連続壁による液状化対策は 沈下量よりもむしろ傾斜量の抑制に大きな効果が期待で きると考えられる．また，液状化被害の代表ともいえる 構造物の沈下量や傾斜量の抑制には, 地中連続壁の壁体 厚や壁体長, 壁体間隔などの幾何学的条件の夕ならず, 壁体の透水性能や強度などの材料条件にも大きく依存寸 るため, 今後は更なる技術開発による高強度, かつ排水 性も高い地盤改良が可能となることに期待したい.

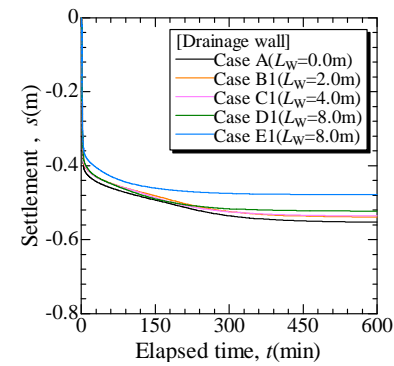

(a) 排水壁

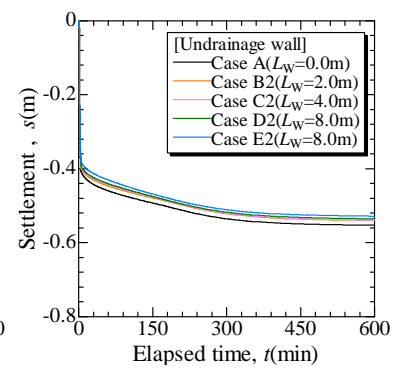

(b) 難透水壁
図-32 構造物の沈下量

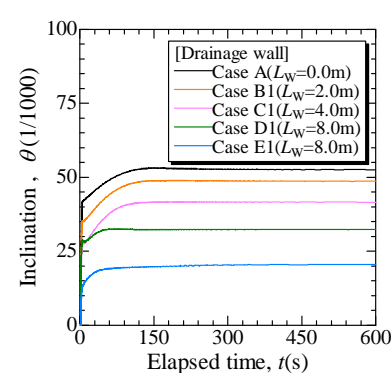

(a)排水壁

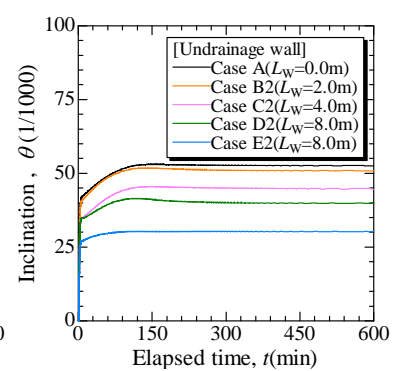

(b) 難透水壁
図-33 構造物の傾斜量

表-7 構造物変位量のまとめ

\begin{tabular}{l|c|c|c}
\hline & $\begin{array}{c}\text { Permeability } \\
k_{\mathrm{w}}(\mathrm{m} / \mathrm{s})\end{array}$ & $\begin{array}{c}\text { Settlement } \\
s(\mathrm{~m})\end{array}$ & $\begin{array}{c}\text { Inclination } \\
\theta(1 / 1000)\end{array}$ \\
\hline Case A & - & $0.554(1.000)$ & $52.50(1.000)$ \\
\hline Case B1 & $1.5 * 10^{4}$ & $0.540(0.975)$ & $48.67(0.927)$ \\
Case B2 & $1.5 * 10^{-9}$ & $0.541(0.977)$ & $50.83(0.967)$ \\
\hline CaseC1 & $1.5 * 10^{4}$ & $0.536(0.968)$ & $41.67(0.794)$ \\
Case C2 & $1.5 * 10^{-9}$ & $0.540(0.975)$ & $44.67(0.851)$ \\
\hline Case D1 & $1.5 * 10^{4}$ & $0.523(0.944)$ & $32.33(0.616)$ \\
Case D2 & $1.5 * 10^{-9}$ & $0.537(0.968)$ & $39.83(0.759)$ \\
\hline CaseE1 & $1.5 * 10^{4}$ & $0.479(0.865)$ & $20.50(0.390)$ \\
CaseE2 & $1.5 * 10^{-9}$ & $0.530(0.957)$ & $30.17(0.575)$ \\
\hline
\end{tabular}

（）は未対策である Case Aを基準とした比率を表す

\section{4. まとめ}

本研究では，既設構造物に対しても適用可能な地中連 続排水壁について振動台実験と有限要素解析による検討 を行った. 以下に本検討によって得られた知見を示寸.

1) 本研究で検討を行った地中連続排水壁による液状化 対策は液状化被害を完全に防止することは困難であ るが，構造物直下の地盤を改良しなくても構造物の 沈下被害をある程度は抑制することが可能である.

2)地中連続排水壁付近や格子内部においては，過剩間 隙水圧が早期に消散することによって地盤の変形が 生じにくい.

3) 3 次元有限要素解析より, 本研究で行った検討は限 定的な条件ではあるが壁状改良は柱状改良に比べて 対策効果が高く壁体自身の変形量も小さい結果とな った．しかし，壁状改良の優位性を断定するために は柱状改良の改良径や改良率, 配置方法などを変え た様々な改良仕様における検討が必要である.

4）地中連続壁による対策効果は，壁体長や壁体剛性の みならず，壁体の排水性にも大きく依存する.

5）排水壁周囲の地盤は排水壁によって早期に剛性が回 復することによって排水壁自身を支え，さらには排 水壁に向かって浸透流が作用寸るため, この剛性回 復と浸透流の両効果によって壁体の崩壊を妨げてい ると考えられる．振動台実験においても周囲の地盤 が液状化していても排水壁は崩壊しなかった. 


\section{参考文献}

1) 風間基樹：2011 年東北地方太平洋沖地震被害の概要 と地盤工学的課題, 地盤工学ジャーナル, Vol.7, No.1, pp.1-11, 2012.

2) 岡二三生, 吉田信之, 甲斐誠士，飛田哲男，肥後陽 介，鳥居宣之，鏡原聖史，中西典明，木元小百合， 山川優樹, 東瀬康孝, 渦岡良介, 京谷孝史 : 東北地 方太平洋沖地震被害調査報告一宮城県北部一, 地盤 工学ジャーナル, Vol.7, No.1, pp.37-55, 2012.

3) 安田進 - 原田健二. 石川敬祐 : 東北地方太平洋沖地 震による千葉県の被害, 地盤工学ジャーナル, Vol.7, No.1, pp.103-115, 2012.

4) 佐藤富男, 若松加寿江 : 過去の地震における液状化 による人的被害, 第 27 回土木学会地震工学論文集, pp.1-4, 2003.

5)田中幸久, 国生剛治, 江刺靖行, 松井家孝 : グラベ ルパイルによる水平地盤の液状化防止について，土 木学会論文集，第 352 号/ III-2，pp.89-98，1984.

6) 田中幸久, 国生剛治, 江刺靖行, 松井家孝：グラベ ルパイルによる水平地盤の二次液状化防止について, 土木学会論文集，第 364 号/ III-4, pp.97-106, 1985.

7) 海野寿康, 林健太郎, 浅田英幸, 居場博之: 遠心載 荷模型実験を用いた過剩間隙水圧消散工法による液 状化対策の効果の検証，土木学会論文集 B3, Vol.68, No.2, pp.I_480-I_485, 2012.

8) 津國正一, 内田明彦, 本多剛, 小西一生 : 格子状地 盤改良による住宅沈下量抑制効果に着目した遠心模 型振動実験, 地盤工学ジャーナル, Vol.9, No.4, pp.767-771, 2014.

9）高橋 英紀，森川 嘉之，津國 正一，福武 毅芳，鈴木 亘, 竹花 和浩: 浮き型格子状固化処理工法の液状化 地盤への適用性に関する実験的検討, 土木学会論文 集 B3, Vol.68, No.2, pp.I_432-I_437, 2012.
10) 東祥二, 原田健二, 仁田尾洋, 橋本則之, 鈴木亮 彦, 初山幸治, 舘下和行, 菅野高弘, 中澤博志 : 実 大実験における格子状固化改良の液状化対策効果に 関する研究，材料，Vol. 59, No. 1, pp. 14-19, 2010.

11) Zhang, F., Ye, B., Noda, T., Nakano, M. and Nakai K.: Explanation of cyclic mobility of soils: Approach by stress-induced anisotropy, Soils and Foundations, Vol.47, No.4, pp.635-648, 2007

12) Ye, B.: Experiment and Numerical Simulation of Repeated Liquefaction -Consolidation of Sand, Doctoral Dissertation, Gifu University, 2007.

13) Hashiguchi, K. and Ueno, M.: Elastoplastic constitutive laws of granular material, Constitutive Equations of Soils, Pro. 9th Int. Conf. Soil Mech. Found. Engrg., Spec. Ses. 9, Murayama, S. and Schofield, A. N. (eds.), Tokyo, JSSMFE, pp.73-82, 1977

14) Asaoka, A., Nakano, M. and Noda. T.: Super loading yield surface concept for the saturated structured soils, Proc. of the Fourth European Conference on Numerical Methods in Geotechnical Engineering-NUMGE98, pp.232-242, 1998.

15) X. H. Bao, Morikawa, Y., Kondo, Y., Nakamura, K. and Zhang F.: Shaking table test on reinforcement effect of partial ground improvement for group-pile foundation and its numerical simulation, Soils and Foundations, Vol.52, No.6, pp.1043-1061, 2012

(2015.6. 23 受付)

\title{
COUNTERMEASURE AGAINST LIQUEFACTION USING DRAINAGE DIAPHRAGM WALL FOCUSED ON THE EFFECT OF DISSIPATION OF WATER PRESSURE
}

\author{
Yukihiro MORIKAWA, Yuya TANAKA, Kenichi MAEDA and Ho CHO
}

Earthquakes constantly hit Japan and liquefaction always lead serious damage to structures. Therefore, countermeasures against the liquefaction are urgently needed to prevent the small structures such as personal houses and underground structures from the damage. Unfortunately, however, countermeasures for small structures are not so intensively studied compared with the massive structures in civil engineering, especially there are few countermeasures for existing structure. In this paper, particular attention is paid to the enhancement effect of the dissipation of excess pore water pressure using drainage diaphragm wall with high permeability and large restraining effect of soft soil. The drainage diaphragm wall is made of the soil materials having high internal frictional angle and permeability, whose countermeasure against liquefaction is investigated by $1 \mathrm{~g}$ shaking table test and finite element analyses. The results obtained in this research can be summarized as follows: (1) by using the drainage diaphragm wall around structure, it is possible to suppress the subsidence and inclination of the structure; (2) Due to the drainage diaphragm wall, the defamations of the wall and the soil near the wall are suppressed significantly due to the quick dissipation of the excess pore water pressure and the restraining effect of the diaphragm wall; (3) improvement effect by the drainage diaphragm wall is higher than those by column-shaped improvement wall, and so does the deformation; (4) improvement effect of the diaphragm wall depends not only on the wall depth, the rigidity of the wall but also on the permeability of the wall ; (5) the wall made of drainage material does not collapse even in the completely liquefied ground due to the strong recovery ability of the effective stress near the wall and the resistance against the horizontal osmotic pressure toward the wall. 